\title{
Cytotoxic effects of Mangifera indica L. kernel extract on human breast cancer (MCF-7 and MDA-MB-231 cell lines) and bioactive constituents in the crude extract
}

\author{
Al-Shwyeh Hussah Abdullah', Abdulkarim Sabo Mohammed ${ }^{1 *}$, Rasedee Abdullahn ${ }^{2,3}$, \\ Mohamed Elwathig Saeed Mirghani ${ }^{4}$ and Mothanna Al-Qubaisi ${ }^{5}$
}

\begin{abstract}
Background: Waterlily Mango (Mangifera indica L.) is thought to be antioxidant-rich, conferred by its functional phytochemicals.

Methods: The potential anticancer effects of the ethanolic kernel extract on breast cancer cells (MDA-MB-231 and MCF-7) using MTT, anti-proliferation, neutral red (NR) uptake and lactate dehydrogenase (LDH) release assays were evaluated. Cytological studies on the breast cancer cells were also conducted, and phytochemical analyses of the extract were carried out to determine the likely bioactive compounds responsible for such effects.

Results: Results showed the extract induced cytotoxicity in MDA-MB-231 cells and MCF-7 cells with $\mathrm{IC}_{50}$ values of 30 and $15 \mu \mathrm{g} / \mathrm{mL}$, respectively. The extract showed significant toxicity towards both cell lines, with low toxicity to normal breast cells (MCF-10A). The cytotoxic effects on the cells were further confirmed by the NR uptake, antiproliferative and $\mathrm{LDH}$ release assays. Bioactive analyses revealed that many bioactives were present in the extract although butylated hydroxytoluene, a potent antioxidant, was the most abundant with $44.65 \%$.

Conclusions: $M$. indica extract appears to be more cytoxic to both estrogen positive and negative breast cancer cell lines than to normal breast cells. Synergistic effects of its antioxidant bioactives could have contributed to the cytotoxic effects of the extract. The extract of $M$. indica, therefore, has potential anticancer activity against breast cancer cells. This potential is worth studying further, and could have implications on future studies and eventually management of human breast cancers.
\end{abstract}

Keywords: Mangifera indica L, kernel extract, MCF-7 cells, MDA-MB-231 cell, Cytotoxicity, Anticancer activity

\section{Background}

Breast cancer causes significant morbidity and mortality among women [1], and metastasis mainly affects outcome of the disease [2]. Lack of effective therapeutic strategies for control and treatment of breast cancers, and the huge financial burden placed on individuals and nations mean urgent action must be taken in the fight against breast cancer. Also, side effects due to conventional pharmacological agents have necessitated the search for

\footnotetext{
* Correspondence: karimsabo@upm.edu.my

${ }^{1}$ Faculty of Food Science and Technology, Universiti Putra Malaysia, 43400 Serdang, Selangor, Malaysia

Full list of author information is available at the end of the article
}

newer therapies mostly in the form of natural products. In recent years, interest in natural products has grown, and in the light of long-term and safe cancer prevention, current approaches have been focused on the use of food and edible medicinal herbs as sources of products that could effectively control cancers [3-5]. This is evident by the fact that approximately $74 \%$ of new anticancer compounds are either natural products or natural product-derived [6-9]. In fact, it has been argued that plants may be sources of multiple bioactive compounds that could provide more benefit than single pharmacological agents against chronic diseases, and this may well be beneficical in managing breast cancer. The antioxidant potentials of plant bioresources, mainly 
contributed by their bioactive compounds, have been closely linked to their abilities to suppress growth of cancer cells, likely through reduced oxidative stress, which may play a role in the development and progression of cellular damages underlying cancerous growth. As such, it has been suggested that antioxidant supplementation may reduce breast cancer recurrence and mortalities [10] and through bioassay systems and animal studies, there have been indications that numerous naturally-occurring antioxidant compounds possess anticancer properties [11,12]. In particular, consumption of foods and beverages rich in polyphenols such as catechins, antocyanines and flavones have been linked to lower occurrence of cancers [13]. Other phenolic compounds claimed to possess biological activities include coumarins, lignans, phenolic acids, flavonoids, quinones, stilbenes, tannins and curcuminoids [14].

Mangifera indica L. is a popular fruit crop in tropical and subtropical areas of the world, specifically Asia, because of its characteristic taste, colour and nutritional value $[15,16]$. It has numerous classes of bioactive compounds and vitamins with different health-promoting characteristics [17]. The ethanolic extract of its peel was observed to have great antioxidant and anti-proliferative properties, attributed to its phenolic content $[18,19]$. Notwithstanding these reports however, the phytochemical profile or therapeutic potential of compounds in the kernel has not been studied. Thus, the phytochemical profile and the potential cytotoxic effects of the kernel extract towards breast cancer cell lines were studied and evaluated.

\section{Methods}

\section{Chemicals and reagents}

Dulbecco's modified Eagle medium (DMEM), thiazoyl blue tetrazolium bromide (MTT), 95\% ethanol, dimethylsulphoxide (DMSO), nicotinamide adenine dinucleotide (reduced form) NADH, fetal bovine serum (FBS), phosphate buffer saline (PBS), trypan blue dye solution, trypsinEDTA, neutral red (NR) solution and antibiotics were purchased from Sigma-Aldrich (St. Louis, MO, USA).

\section{Raw materials}

Waterlily mango (Mangifera indica L.) fruits were procured from a local market in Kuala Lumpur, Malaysia and were identified by a resident botanist and voucher specimen (Mr. Shamsul Khamis) from Institute of Bioscience, Universiti Putra Malaysia under the voucher specimen (SK2448/14). The mango kernel was manually isolated from the stone and flesh.

\section{Preparation of crude extract}

$M$. indica kernels were soaked in water, and washed to remove adhering flesh. They were then air-dried, and subsequently kept in an oven at $45^{\circ} \mathrm{C}$ for 2 days. The dried kernels were finely ground with a Waring blender
7011HS (Osaka Chemical Co. Ltd., Osaka, Japan) and stored at $4^{\circ} \mathrm{C}$ until analysis. Ethanol (95\%) was added to the kernel powder at 10:1 (v/w) and the mixture shaken continuously at $200 \mathrm{rpm}$ and $37^{\circ} \mathrm{C}$ for $24 \mathrm{~h}$ in an incubator shaker (INNOVA 4000, New Jersey, USA). Insoluble materials were then removed by filtration and the filtrates centrifuged for $10 \mathrm{~min}$ at $4000 \mathrm{rpm}$ using Benchtop Centrifuge Z200A (Labnet International, Inc., Woodbridge, NJ, USA). The residues were discarded and the supernatant dried using 1 L Rotary Evaporator N1001S-WD (Tokyo Rikakikai Co., Ltd., Tokyo, Japan) until the extract was fully concentrated. After determining the yield, the concentrated extract was then dissolved in DMSO and stored in a freezer at $-20^{\circ} \mathrm{C}[20]$ before further analyses.

\section{In vitro assay}

Two human breast cancer cell lines, MDA-MB-231 and MCF-7 cells and one normal cell line, MCF-10A cells were obtained from the American Type Culture Collection (ATCC: Rockville, MD, USA). Cells were cultured in DMEM supplemented with 10\% FBS and 1\% antibiotics $\left(100 \mathrm{U} / \mathrm{ml}\right.$ penicillin) in an incubator at $37^{\circ} \mathrm{C}$ with $5 \% \mathrm{CO}_{2}$.

\section{MTT assay}

MCF-7, MDA-MB-231 and MCF-10A cells were seeded into 96 -well plates at densities of $2 \times 10^{3} /$ well under $5 \%$ $\mathrm{CO}_{2}$ at $37^{\circ} \mathrm{C}$ for $24 \mathrm{~h}$ as reported previously [21]. The cells were then either treated with different concentrations of ethanolic extract of the $M$. indica kernel $(10-1000 \mu \mathrm{g} / \mathrm{mL})$ or doxorubicin $(0.1-10 \mu \mathrm{g} / \mathrm{mL})$ as positive control. After $72 \mathrm{~h}$ incubation, $20 \mu \mathrm{L}$ of MTT solution $(5 \mathrm{mg} / \mathrm{mL})$ was pipetted into each well and incubated for another $4 \mathrm{~h}$. The medium was later discarded and the formazan precipitate was dissolved in DMSO. The absorbance of the mixtures was determined using a microtiter plate reader at 570 and $630 \mathrm{~nm}$ (background) and the cell viability expressed as percentage of live cells relative to controls. All experiments were performed in triplicates. The $\mathrm{IC}_{50}$ was generated from the dose-response curve for each cell line.

\section{Anti-proliferation assay}

MCF-7 and MDA-MB-231 cells were seeded into 6-well plates at densities of $1 \times 10^{4}$ cells/well and allowed to incubate for $24 \mathrm{~h}$ for cell attachment. These exponentially growing cells were then exposed to 5,10 and $50 \mu \mathrm{g} / \mathrm{mL}$ concentrations of the extract and the plates incubated at $37^{\circ} \mathrm{C}$ under $5 \% \mathrm{CO}_{2}$, for 24,48 , and $72 \mathrm{~h}$. At the end of the incubation periods, the medium was aspirated off and washed with cold PBS followed by the addition of $1 \mathrm{~mL}$ of $0.05 \%$ trypsin-EDTA. The plates were then incubated at $37^{\circ} \mathrm{C}$ for $15 \mathrm{~min}$ and after majority of the cells had detached from the plate, they were harvested by spinning the suspension for $10 \mathrm{~min}$ at $1000 \mathrm{rpm}$ using Benchtop Centrifuge Z200A (Labnet International, Inc., Woodbridge, NJ, USA) 
and the supernatant discarded. Twenty microliters of the cell pellet were re-suspended in $20 \mu \mathrm{L}$ of $0.4 \%$ trypan blue solution. The dye-excluding viable cells were counted microscopically using a hemocytometer, and expressed as percent of control cells that were still viable.

\section{Neutral red uptake assay}

The cells were seeded in 96-well plates and incubated overnight at $37^{\circ} \mathrm{C}$ under $5 \% \mathrm{CO}_{2}$ until they reached $60 \%$ confluence. The medium was then discarded and replaced with $200 \mu \mathrm{L}$ of fresh growth medium containing the same concentrations of the kernel extract as that used in the MTT assay. Untreated cells under the same conditions were used as controls. The plates were incubated at $37^{\circ} \mathrm{C}$ under $5 \% \mathrm{CO}_{2}$ for 24,48 and $72 \mathrm{~h}$ and the cells were then washed three times with $200 \mu \mathrm{L}$ of PBS. The plates were re-incubated for $3 \mathrm{~h}$ at $25^{\circ} \mathrm{C}$ in medium containing $200 \mu \mathrm{L}$ NR solutions, and the cells subsequently washed to remove the NR solution. Cells were then exposed to fixing solution consisting of $1 \% \mathrm{CaCl}_{2}$ and $0.5 \%$ formaldehyde in milli-Q water for 2 min followed by two washes with $1 \%$ acetic acid and $50 \%$ ethanol in milli-Q water. After a second wash, the plates were incubated for $10 \mathrm{~min}$ and then read in a microplate reader at $540 \mathrm{~nm}$.

\section{Lactate dehydrogenase release assay}

The permeability of the cell membrane of MCF-7 and MDA-MB-231 cell lines after treatment with ethanolic kernel extract was determined by $\mathrm{LDH}$ release assay. The cells were seeded in 96-well plates in $100 \mu \mathrm{L}$ of media, and then treated with different concentrations of ethanolic extract of the $M$. indica kernel $(10-1000 \mu \mathrm{g} / \mathrm{mL})$ or doxorubicin $(0.1-100 \mu \mathrm{g} / \mathrm{mL})$. The treated cells then were incubated for $18 \mathrm{~h}$, after which $40 \mu \mathrm{L}$ of the medium was transferred to a new 96-well plate and further incubated for $72 \mathrm{~h}$ to determine LDH release. Forty microliter of $6 \%$ triton X-100 was added to the original 96-well plates to determine the total LDH concentration. An aliquot of $100 \mu \mathrm{L}$ of $4.6 \mathrm{mM}$ pyruvic acid in $0.1 \mathrm{M}$ potassium phosphate buffer ( $\mathrm{pH} 7.5$ ) was added to each well of the plate containing the medium followed by $100 \mu \mathrm{L}$ of $0.4 \mathrm{mg} / \mathrm{mL}$ reduced $\beta-\mathrm{NADH}$ in $0.1 \mathrm{M}$ potassium phosphate buffer $(\mathrm{pH} 7.5)$. The kinetic change in absorbance at $340 \mathrm{~nm}$ was read for $1 \mathrm{~min}$ in an ELISA microplate reader. Change in 0.001 absorbance unit/min was considered to be equivalent to $1 \mathrm{U} / \mathrm{L}$ of LDH activity [21]. To determine total LDH activity, the procedure was repeated with $40 \mu \mathrm{L}$ total cell lysate from untreated controls following similar way as stated above. The $\mathrm{LDH}$ release was determined as percentage of $\mathrm{LDH}$ in medium in comparison to total LDH in cell lysate of each respective well using the following equation: $100 \% * \mathrm{LDH}_{\text {out }} /\left(\mathrm{LDH}_{\text {out }}+\mathrm{LDH}_{\text {in }}\right)$. Values are expressed as mean \pm std. dev. $(n=3)$.

\section{Bioactive compounds analysis}

The crude ethanolic extract of Waterlily kernel (100 mg) was dissolved in $10 \mathrm{~mL}$ of hexane and $100 \mu \mathrm{L}$ of $2 \mathrm{~N}$ potassium hydroxide in methanol was added to the mixture and vortexed for $30 \mathrm{sec}$. The solution was further separated by centrifugation at $10,000 \mathrm{rpm}$ for 10 minutes and the supernatant $(1.5 \mathrm{~mL})$ was transferred into a vial and analyzed using Gas chromatography-mass spectrometry following the method of Hema et al. [22]. The analysis of the extract was performed using a Perkin-Elmer GC claurus 500 system. The gas chromatograph was interfaced to a mass spectrometer, equipped with Elite-1 fused silica capillary column $(30 \mathrm{~m} \times 0.25 \mathrm{~mm}$ ID $\times 1 \mu \mathrm{m} d f$, composed of $100 \%$ Dimethyl poly siloxane). Compounds were detected using an electron ionization system with ionization energy of $70 \mathrm{eV}$. Helium gas (99.999\%) was used as the carrier gas at a constant flow rate of $1 \mathrm{~mL} / \mathrm{min}$ and an injection volume of $0.5 \mu \mathrm{L}$, with a split ratio of $10: 1$. The injector temperature was $250^{\circ} \mathrm{C}$ while that of the ion source was $280^{\circ} \mathrm{C}$. The oven temperature was set at $110^{\circ} \mathrm{C}$ held for $2 \mathrm{~min}$ with an increase of $10^{\circ} \mathrm{C} / \mathrm{min}$ to $200^{\circ} \mathrm{C}$, then at $5^{\circ} \mathrm{C} / \mathrm{min}$ to $280^{\circ} \mathrm{C}$ held for $9 \mathrm{~min}$. Mass spectra were taken at $70 \mathrm{eV}$; a scan interval of $0.5 \mathrm{sec}$ and fragments from 45 to $450 \mathrm{Da}$. Total GC running time was $60 \mathrm{~min}$.

Interpretation of mass spectrum from GC-MS was conducted using the database of National Institute of Standards and Technology (NIST). The spectra of the unknown compounds were compared with those of the known compounds stored in the NIST library. The name, molecular weight and structure of the compounds extracted from the test materials were ascertained.

\section{Results and discussion MTT assay}

Two human breast carcinoma cell lines, estrogen receptor negative (ER-) MDA-MB-231 cells and estrogen receptor positive $(\mathrm{ER}+) \mathrm{MCF}-7$ cells were used to determine the cytotoxicity of the $M$. indica kernel extract against the cells. Non-tumorous MCF-10A cells were used as controls. The survival of the three human breast-derived cells after treatment with the kernel extract and doxorubicin after $72 \mathrm{~h}$ was determined. The responses of MCF-7 and MDA-MB231 cancer cells to increasing concentrations of the kernel extract and doxorubicin are shown in Figures 1 and 2, respectively. The results showed the tendency of both cell lines to decrease sharply upon treatment with low extract and doxorubicin concentrations, with a tapering response intensity as the concentrations of the extract and doxorubicin were increased.

Following $72 \mathrm{~h}$ incubation with $15.6 \mu \mathrm{g} / \mathrm{mL}$ of the extract, MCF-7 and MDA-MB-231 cell retained 53 and $76 \%$ viability, respectively, indicating decrease in cell growth by 47 and $24 \%$ for the MCF-7 and MDA-MB-231 cell, respectively. The MCF-10A cells similarly treated with 

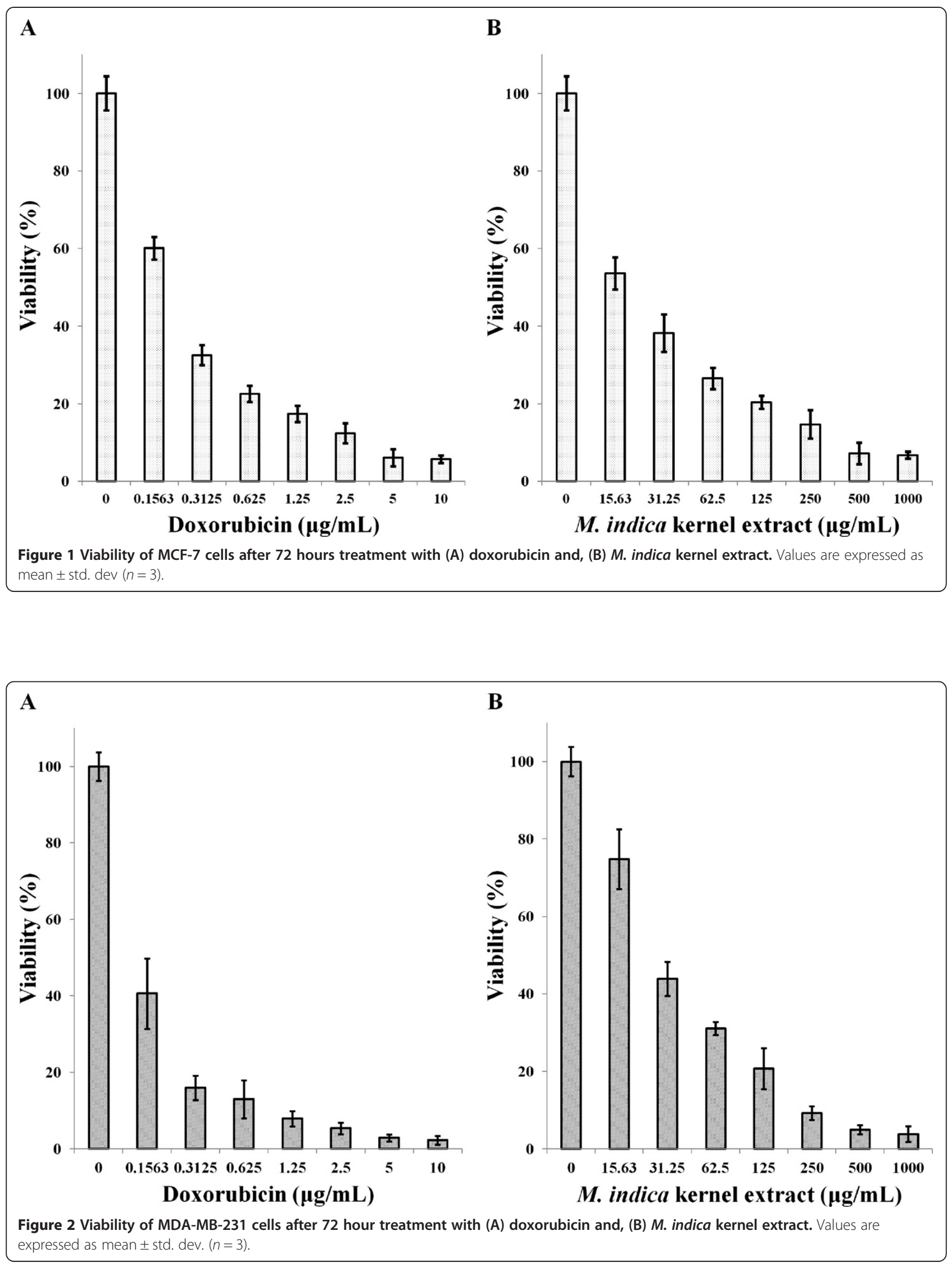
kernel extract showed only $7 \%$ decrease in growth thereby retaining 93\% viability (Figure 3 ). This insignificant decrease in growth of MCF-10A 223 as compared to considerably higher values seen in MCF-7 and MDA-MB-231 indicates that the extract exhibited low toxicity towards normal cells and significantly higher toxicity towards the cancer cells. The $\mathrm{IC}_{50}$ values of the kernel extract after $72 \mathrm{~h}$ treatment ranged between 15 and $30 \mu \mathrm{g} / \mathrm{mL}$ for MCF-7 and MDA-MB-231 cell lines, while it was found to be significantly higher $(149 \mu \mathrm{g} / \mathrm{mL})$ for the normal MCF-10A cells (Figure 4). The kernel extract showed lower $\mathrm{IC}_{50}$ values for the cancer cells compared to the normal breast cell, suggesting that the extract could have huge potentials as an anti-cancer agent. These findings mirrored those of Abu Bakar et al. [23], who demonstrated the anti-cancer potentials of the seed kernel of Mangifera pajang (Banbangan) on the same type of cell lines following similar treatments.

\section{Anti-proliferation assay}

Figure 5 illustrates the anti-proliferative effects of the kernel extract on MCF-7 and MDA-MB-231 cells. The percentage survival of the MCF-7 cells after 24, 48 and $72 \mathrm{~h}$ of incubation with $10 \mu \mathrm{g} / \mathrm{mL}$ of extract were 96,77 and $52 \%$, respectively. However, MDA-MB-231 cells similarly treated with the kernel extract did not show as much reduction in viability as the MCF-7 cells with values of 98, 93 and $71 \%$, respectively. This indicated that the kernel extract could have greater effect on the viability of MCF-7 than MDA-MB-231 cells.

\section{NR uptake}

The NR assay used to determine lysosomal activity of MCF-7 and MDA-MB-231 cells treated with the kernel extract showed lower sensitivity than the MTT assay although a significant decrease in lysosomal activity in a dose-dependent manner was observed (Figure 6). The lower sensitivity may be due to the lower numbers of lysosomes in the breast cancer cell lines. NR uptake assay is based on the capacity of viable cells to bind and incorporate the supravital dye, NR, into lysosomes. $\mathrm{NR}$ is a positively charged dye that passively diffuses across cellular membrane and accumulates in the lysosomes, and the intensity of its staining is directly proportional to the number of viable cells.

\section{LDH release assay}

Cell death in culture was also determined by the release of $\mathrm{LDH}$ into the incubation medium. The $\mathrm{LDH}$ release curves for MCF-7 and MDA-MB-231 cell lines treated with different concentrations of the kernel extract suggested that the cytotoxic effect of the extract was concentration-dependent (Figure 7). The percentage of LDH release from MCF-7 cell lines after $72 \mathrm{~h}$ exposure to $15,31,62$, and $125 \mu \mathrm{g} / \mathrm{mL}$ extract concentrations were $57,73,81$ and $86 \%$, respectively. This effect is

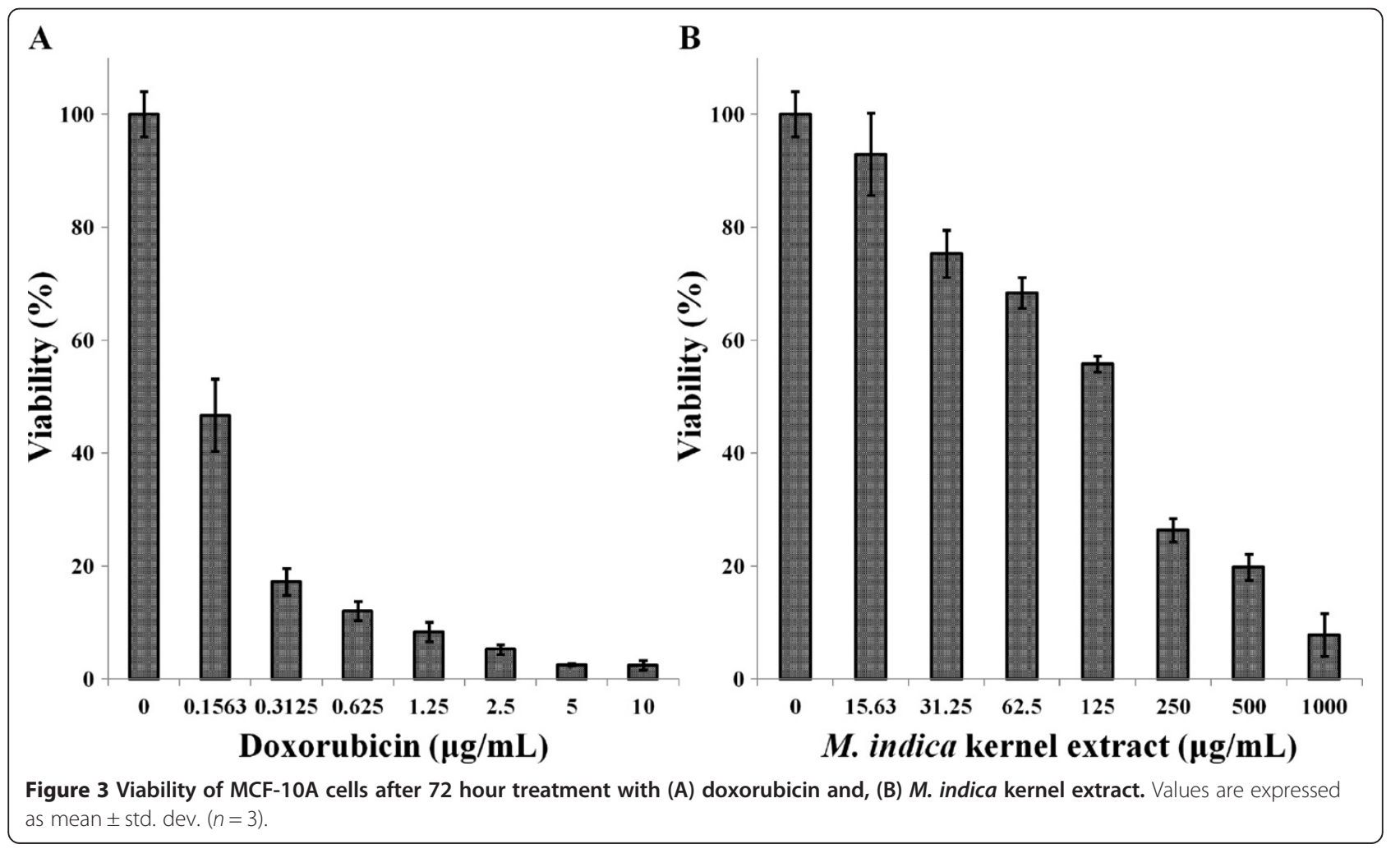





Figure 5 Viability of breast cancer cells treated with $M$. indica kernel extract after 24, 48 and 72 hours, (A) MCF-7 cell and (B) MDA-MB-231 cell. Values are expressed as mean \pm std. $\operatorname{dev}(n=3)$. 

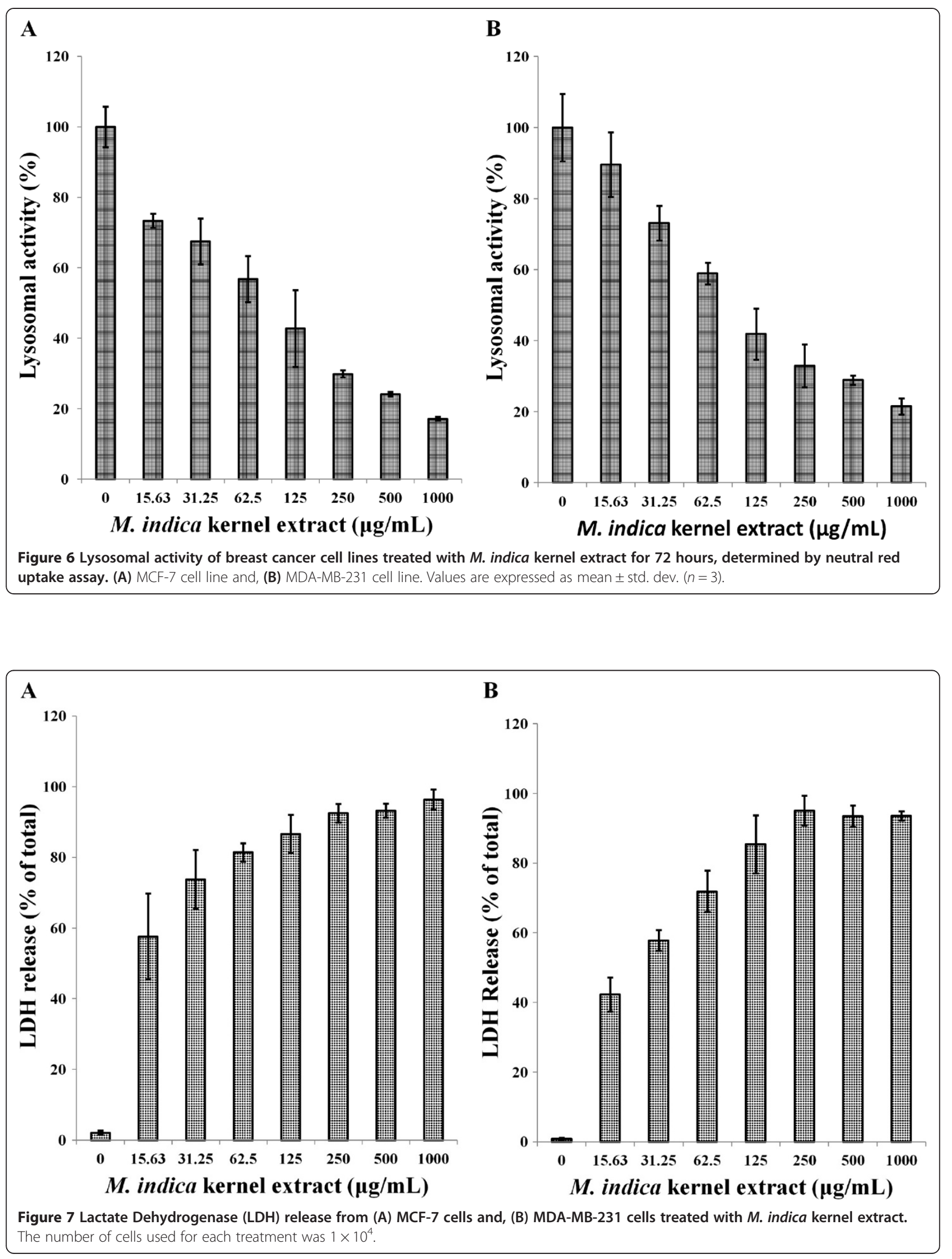


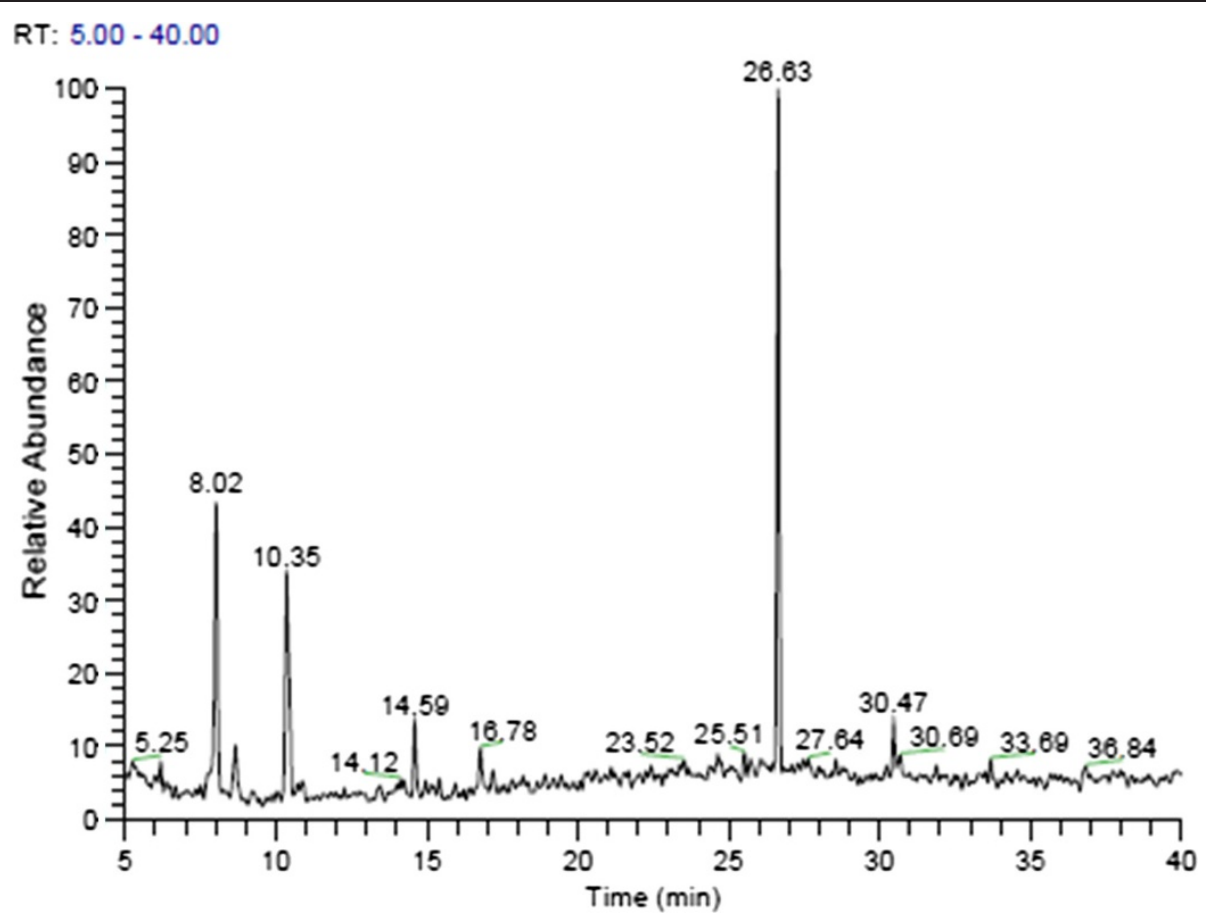

Figure 8 GC-MS chromatogram of the ethanolic extract of the Mango (Waterlily) kernel extract, giving out twelve apparent compounds.

greater than those observed for the same concentration of extract on MDA-MB-231 cell lines with 42, 58, 72 and $85 \%$, respectively after $72 \mathrm{~h}$. However, higher concentrations $(250-1000 \mu \mathrm{g} / \mathrm{mL})$ of the extract produced even greater LDH release on both cells.

\section{Analysis of bioactive compounds}

Twelve major compounds were identified in the kernel extract of Mangifera indica L. The GC-MS chromatogram is shown in Figure 8, and the corresponding compounds with their retention times, molecular formulae, molecular weights (MW), and concentrations (\%) are shown in Table 1.

Of the twelve compounds detected, five compounds have been previously reported to possess anticancer potentials, including phenol, 4,6-di (1,1-dimethylethyl)-2-methyl(44.65\%) [24], Fumaric acid, 2-decyl undecyl ester (2.85\%) [25], Isoheptadecanol (1-Hexadecanol, 2-methyl) (2.74\%) [26], Apigenin 7-glucoside (1.74\%) [27,28], and cis-5Dodecenoic acid, (3-cyanopropyl) dimethylsilyl ester (1.47\%) [29]. In addition, the other compounds have also been shown to exhibit some biological activities including antioxidant activity. Phenol, 4,6-di (1,1-dimethylethyl)-2methyl- also known as butylated hydroxytoluene (BHT) was found to be the most abundant in the extract, and is a common food additive that is reported to have high antioxidant potentials. It is commonly used in the pharmaceutical, cosmeceutical and other industries largely due to its antioxidant properties. Apigenin 7-glucoside, a phenolic compound with potent antioxidant and anticancer potentials [30], was also found to be present in the extract.

It is most probable that the cytotoxic effects of the extract of Mangifera indica L. on breast cancer cells as shown in this study are due to more than one bioactive compound in view of the multiple compounds detected in the extract and since a crude extract was used. Already, some of the compounds found in the extract have been reported to have effects favorable for an anticancer activity, and these effects could have been synergistically contributed to the anticancer potentials observed in the extract.

\section{Conclusions}

The MTT, anti-proliferation, NR uptake and LDH release assays used to evaluate the cytotoxicity of ethanolic kernel extract of Mangifera indica L on MCF-7 and MDA-MB231 cell lines showed that the extract is significantly cytotoxic to these cell lines in a dose-dependent manner, and considerably less so towards normal breast cells MCF-10A. These findings highlights the potentials of Mangifera indica $\mathrm{L}$ extract in the treatment of breast cancer. Its therapeutic potential is huge and can be used as alternative to or supplementation for the various therapy currently used in the treatment of breast cancer. However there is a need to identify the actual components responsible for this cytotoxicity and to isolate them and to study their effect in vivo to ascertain their efficacies and or any side effects. The 
Table 1 Common biological activities of the phytocomponents identified in the ethanolic extract of Waterlily kernel extract

\begin{tabular}{|c|c|c|c|c|}
\hline No. & $\begin{array}{l}\text { Retention } \\
\text { time (min) }\end{array}$ & Name of compound & $\begin{array}{l}\text { Molecular formula } \\
\text { and molecular } \\
\text { weight (MW) }\end{array}$ & $\begin{array}{c}\text { Peak } \\
\text { area } \\
(\%) \\
\end{array}$ \\
\hline \multirow[t]{2}{*}{1.} & \multirow[t]{2}{*}{8.02} & \multirow{2}{*}{$\begin{array}{l}\text { 1-Butanol, 3-methyl-, } \\
\text { acetate }\end{array}$} & $\mathrm{C}_{7} \mathrm{H}_{14} \mathrm{O}_{2}$ & \multirow[t]{2}{*}{17.85} \\
\hline & & & MW: 130 & \\
\hline \multirow[t]{2}{*}{2.} & \multirow[t]{2}{*}{10.35} & \multirow{2}{*}{$\begin{array}{c}\text { Butane, 1, } \\
\text { 1-diethoxy-3-methyl- }\end{array}$} & $\mathrm{C}_{9} \mathrm{H}_{20} \mathrm{O}_{2}$ & \multirow[t]{2}{*}{20.79} \\
\hline & & & MW: 160 & \\
\hline \multirow[t]{2}{*}{3.} & \multirow[t]{2}{*}{14.59} & \multirow{2}{*}{$\begin{array}{l}\text { Propane, 1, } \\
\text { 1,3-triethoxy- }\end{array}$} & $\mathrm{C}_{9} \mathrm{H}_{20} \mathrm{O}_{3}$ & \multirow[t]{2}{*}{3.00} \\
\hline & & & MW: 176 & \\
\hline \multirow[t]{2}{*}{4.} & \multirow[t]{2}{*}{16.77} & \multirow{2}{*}{$\begin{array}{c}\text { Ethaneperoxoic } \\
\text { acid, 1-cyano-1- } \\
\text { (2-methylphenyl) } \\
\text { ethyl ester }\end{array}$} & $\mathrm{C}_{12} \mathrm{H}_{13} \mathrm{NO}_{3}$ & \multirow[t]{2}{*}{2.03} \\
\hline & & & MW: 219 & \\
\hline \multirow[t]{2}{*}{5.} & \multirow[t]{2}{*}{23.54} & \multirow[t]{2}{*}{ Apigenin 7-glucoside } & $\mathrm{C}_{21} \mathrm{H}_{20} \mathrm{O}_{10}$ & \multirow[t]{2}{*}{1.74} \\
\hline & & & MW: 432 & \\
\hline \multirow[t]{2}{*}{6.} & \multirow[t]{2}{*}{26.08} & \multirow[t]{2}{*}{ Disperse Red 11} & $\mathrm{C}_{15} \mathrm{H}_{12} \mathrm{~N}_{2} \mathrm{O}_{3}$ & \multirow[t]{2}{*}{5.72} \\
\hline & & & MW: 268 & \\
\hline \multirow[t]{2}{*}{7.} & \multirow[t]{2}{*}{26.63} & \multirow{2}{*}{$\begin{array}{c}\text { Phenol, 4,6-di } \\
\text { (1,1-dimethylethyl)- } \\
\text { 2-methyl- (Butylated } \\
\text { Hydroxytoluene, BHT) }\end{array}$} & $\mathrm{C}_{15} \mathrm{H}_{24} \mathrm{O}$ & \multirow[t]{2}{*}{44.65} \\
\hline & & & MW: 220 & \\
\hline \multirow[t]{2}{*}{8.} & \multirow[t]{2}{*}{30.47} & \multirow[t]{2}{*}{ Chlorazanil } & $\mathrm{C}_{9} \mathrm{H}_{8} \mathrm{ClN}_{5}$ & \multirow[t]{2}{*}{4.73} \\
\hline & & & MW: 221 & \\
\hline \multirow[t]{2}{*}{9.} & \multirow[t]{2}{*}{30.69} & Isoheptadecanol & $\mathrm{C}_{17} \mathrm{H}_{36} \mathrm{O}$ & 2.74 \\
\hline & & & MW: 256 & \\
\hline 10. & 30.82 & cis-5-Dodecenoic acid, & $\mathrm{C}_{18} \mathrm{H}_{33} \mathrm{NO}_{2} \mathrm{Si}$ & 1.47 \\
\hline & & $\begin{array}{l}\text { (3-cyanopropyl) } \\
\text { dimethylsilyl ester }\end{array}$ & MW: 323 & \\
\hline 11. & 32.78 & Fumaric acid, & $\mathrm{C}_{25} \mathrm{H}_{46} \mathrm{O}_{4}$ & 2.85 \\
\hline & & & MW: 410 & \\
\hline 12. & 36.84 & Phthalic acid, & $\mathrm{C}_{21} \mathrm{H}_{32} \mathrm{O}_{4}$ & 2.47 \\
\hline & & & MW: 348 & \\
\hline
\end{tabular}

concerns of side effects with pharmacological agents, and growing interest in plant bioresources for treatment of cancers mean this extract could have important role in future studies on the mangement of breast cancer.

\section{Abbreviations}

DMEM: Dulbecco's modified Eagle medium; DMSO: Dimethylsulphoxide; ER-: Estrogen receptor negative; ER+: Estrogen receptor positive; FBS: Fetal bovine serum; GC-MS: Gas chromatography-mass spectrometry; LDH: Lactate dehydrogenase; MTT: Thiazoyl blue tetrazolium bromide; NADH: Nicotinamide adenine dinucleotide; NR: Neutral red; PBS: Phosphate buffer saline.

\section{Competing interest}

The author's declared that they have no cmpeting interests.

\section{Author's contributions}

AHA designed the study and carried out most of the experimental parts, while MA contributed to the cell culture assays. ASM, RA and MESM contributed towards supervision of the work. They also read, revised and approved the final manuscript for submission critically. All authors read and approved the final manuscript.

\section{Acknowledgements}

This research was funded by University Putra Malaysia through the Research University Grant (RUGS), Project No. 02-02-12-1724RU.

\section{Author details}

${ }^{1}$ Faculty of Food Science and Technology, Universiti Putra Malaysia, 43400 Serdang, Selangor, Malaysia. ${ }^{2}$ Faculty of Veterinary Medicine, Universiti Putra Malaysia, 43400 Serdang, Selangor, Malaysia. ${ }^{3}$ Institute of Bioscience, Universiti Putra Malaysia, 43400 Serdang, Selangor, Malaysia. ${ }^{4}$ Department of Biotechnology Engineering Faculty of Engineering, International Islamic, University Malaysia (IIUM), P.O. BOX 10, 50728 Kuala Lumpur, Malaysia. ${ }^{5}$ Department of Cell and Molecular Biology, Faculty of Biotechnology, Universiti Putra, Malaysia, 43400 Serdang, Selangor, Malaysia.

Received: 16 November 2013 Accepted: 23 June 2014

Published: 25 June 2014

\section{References}

1. Angelopoulos N, Barbounis V, Livadas S, Kaltsas D, Tolis G: Effects of estrogen deprivation due to breast cancer treatment. Endocr Relat Cancer 2004, 11:523-535.

2. Jemal A, Siegel R, Ward E, Murray T, Xu J, Smigal C, Thun MJ: Cancer Statistics. CA Cancer J Clin 2006, 56:106-130.

3. Ferguson PJ, Kurowska E, Freeman DJ, Chambers AF, Koropatnick DJ: A flavonoid fraction from cranberry extract inhibits proliferation of human tumor cell lines. J Nutr 2004, 134:1529-1535.

4. Jo EH, Hong HD, Ahn NC, Jung JW, Yang SR, Park JS, Kim SH, Lee YS, Kang KS: Modulations of the $\mathrm{BCl}-2 / \mathrm{Bax}$ family were involved in the chemopreventive effects of licorice root (Glycyrrhiza uralensis Fisch) in MCF-7 human breast cancer cell. J Agric Food Chem 2004, 52:1715-1719.

5. Mukherjee AK, Basu S, Sarkar N, Ghosh AC: Advances in cancer therapy with plant based natural products. Curr Med Chem 2001, 8:1467-1486.

6. Chen MS, Chen D, Dou QP: Inhibition of proteasome activity by various fruits and vegetables is associated with cancer cell death. In Vivo 2004, 18:73-80.

7. Cragg GM, Newman DJ: Plants as a source of anti-cancer agents. J Ethnopharmacol 2005, 100:72-79.

8. Tan G, Gyllenhaal C, Soejarto DD: Biodiversity as a source of anticancer drugs. Curr Drug Targets 2006, 7:265-277.

9. Ivanova D, Gerova D, Chervenkov T, Yankov T: Polyphenols and antioxidant capacity of Bulgarian medicinal plants. J Ethnopharmacol 2005, 96:145-150.

10. Fleischauer AT, Simonsen N, Arab L: Antioxidant supplements and risk of breast cancer recurrence and breast cancer-related mortality among postmenopausal women. Nutr Cancer 2003, 46:15-22.

11. Aziz MH, Kumae R, Ahmad N: Cancer chemoprevention by resveratrol: In vitro and in vivo studies and the underlying mechanisms. Int J Oncol 2003, 23:17-28. Review.

12. Primchanien $M$, Nuttavut $K$, Sineenart $K$, Omboon $L$, Narongchai $P$, Neelobol $\mathrm{N}$ : Antiproliferation, antioxidation and induction of apoptosis by Garcinia mangostana (mangosteen) on SKBR3 human breast cancer cell line. J Ethnopharmacol 2004, 92:161-166.

13. Naasani I, Oh-Hashi F, Oh-Hara T, Feng WY, Johnston J, Chan K, Tsuruo T: Blocking telomerase by dietary polyphenols is a major mechanism for limiting the growth of human cancer cells in vitro and in vivo. Cancer Res 2003, 63:824-830.

14. Cai Y, Luo Q, Sun M, Corke H: Antioxidant activity and phenolic compounds of 112 traditional Chinese medicinal plants associated with anticancer. Life Sci 2004, 74:2157-2184.

15. Kim Y, Brecht JK, Talcott ST: Antioxidant phytochemical and fruit quality changes in mango (Mangifera indica L.) following hot water immersion and controlled atmosphere storage. Food Chem 2007, 105:1327-1334.

16. Krishna H, Singh SK: Biotechnological advances in mango (Mangifera indica L.) and their future implication in crop improvement: a review. Biotech Adv 2007, 25:223-243. Review.

17. Robles-Sanchez RM, Rojas-Grau MA, Odriozola-Serrano I, Gonzalez-Aguilar GA, Martin-Belloso O: Effect of minimal processing on bioactive 
compounds and antioxidant activity of fresh-cut 'Kent' mango (Mangifera indica L.). Postharvest Biology and Tech 2009, 51:384-390.

18. Ling LT, Yap SA, Radhakrishnan AK, Subramaniam T, Cheng HM, Palanisamy UD: Standardised Mangifera indica extract is an ideal antioxidant. Food Chem 2009, 113:1154-1159.

19. Kim H, Moon JY, Kim H, Lee D-S, Cho M, Choi H-K, Kim YS, Mosaddik A, Cho SK: Antioxidant and antiproliferative activities of mango (Mangifera indica $\mathrm{L}$.) flesh and peel. Food Chem 2010, 121:429-436.

20. Suhr Kl, Nielsen PV: Antifungal activity of essential oils evaluated by two different application techniques against rye bread spoilage fungi. J App/ Microbiol 2003, 94:665-674.

21. Al-Qubaisi M, Rozita R, Yeap S-K, Omar A-R, Ali A-M, Alitheen NB: Selective cytoxicity of goniothalamin against hepatoblastoma HepG2 cells. Molecules 2011, 16:2944-2959.

22. Hema R, Kumaravel S, Gomathi S, Sivasubramaniam C: Gas chromatography-Mass Spectroscopic analysis of Lawsonia inermis leaves. New York Sci J 2010, 3:141-143.

23. Abu Bakar MF, Mohamad M, Rahmat A, Burr SA, Fry JR: Cytoxicity, cell cycle arrest and apoptosis in breast cancer cell lines exposed to an extract of the seed kernel of Mangifera pajang (bambangan). Food Chem Toxicol 2010, 48:1688-1697.

24. Hocman G: Chemoprevention of cancer: phenolic antioxidants (BHT, BHA). Int J Biochem 1988, 20:639-651.

25. Kuroda K, Teraro K, Akao M: Inhibitory effect of fumaric acid on hepatocarcinogenesis by thioacetamide in rats. J Nat/ Cancer Inst 1987, 79:1047-1051.

26. Okokon JE, Dar A, Choudhary MI: Immunomodulatory, cytotoxic and antileishmanial activity of phytoconstituents of Croton zambesicus. Phytopharmacol 2013, 4:31-40.

27. El-Alfy TS, El-Sawi SA, Sleem A, Moawad DM: Investigation of Flavonoidal Content and biological activities of Chorisia Insignis Hbk. leaves. Austr J Basic Appl Sci 2010, 4:1334-1348.

28. Gulluce M, Orhan F, Yanmis D, Arasoglu T, Guvenalp Z, Dermirezer LO: Isolation of a flavonoid, apigenin 7-O-glucoside, from Mentha longifolia (L.) Hudson subspecies longifolia and its genotoxic potency. Toxicol Ind Health 2013. doi:10.1177/0748233713475511.

29. Posner GH, Ploypradith P, Hapangama W, Wang D, Cumming JN, Dolan P, Kensler TW, Klinedinst D, Shapiro TA, Zheng QY, Murray CK, Pilkington LG, Jayasinghe LR, Bray JF, Daughenbaugh R: Trioxane dimers have potent antimalarial, antiproliferative and antitumor activities in vitro. Bioorgan Med Chem 1997, 5:1257-1265.

30. Nakazaki E, Tsolmon S, Han J, Isoda H: Proteomic study of granulocytic differentiation induced by apigenin 7-glucoside in human promyelocytic leukemia HL-60 cells. Eur J Nutr 2013, 52:25-35.

doi:10.1186/1472-6882-14-199

Cite this article as: Abdullah et al.: Cytotoxic effects of Mangifera indica L. kernel extract on human breast cancer (MCF-7 and MDA-MB-231 cell lines) and bioactive constituents in the crude extract. BMC Complementary and Alternative Medicine 2014 14:199.

\section{Submit your next manuscript to BioMed Central and take full advantage of:}

- Convenient online submission

- Thorough peer review

- No space constraints or color figure charges

- Immediate publication on acceptance

- Inclusion in PubMed, CAS, Scopus and Google Scholar

- Research which is freely available for redistribution 